\title{
THE TECHNOLOGY OF OBTAINING FLEXIBLE DENTURES IN DENTAL PRACTICE, THEORETICAL AND PRACTICAL ASPECTS
}

\author{
MĂDĂLINA ADRIANA MALIȚA ${ }^{1}$, CAMELIA IONESCU ${ }^{2}$, VIOREL ȘTEFAN PERIEANU ${ }^{3}$, \\ MIHAI BURLIBASA ${ }^{4}$, MAGDALENA NATALIA DINA ${ }^{5}$, RADU COSTEA ${ }^{6}$, MĂDĂLINA \\ VIOLETA PERIEANU ${ }^{7}$, RALUCA COSTEA ${ }^{8}$, IULIANA BABIUC ${ }^{9}$, IRINA ADRIANA BEURAN ${ }^{10}$, \\ GABRIELA TĂNASE ${ }^{11}$, MIHAELA CHIRILA ${ }^{12}$, MIHAI DAVID ${ }^{13}$, IOANA VOINESCU ${ }^{14}$, LILIANA \\ MORARU ${ }^{15}$
}

1,2,3,4,5,6,7,8,9,10,11,12,13,14 “Carol Davila” University of Medicine and Pharmacy Bucharest, ${ }^{15}$ "Titu Maiorescu” University of Medicine and Pharmacy, Bucharest

Keywords: $\quad$ flexible Abstract: Flexible dentures are an increasingly interesting prosthetic alternative both for dental dentures, edentulous practitioners (dentists and dental technicians), but also for patients. This type of prosthetic restoration spaces, acrylic partial can rehabilitate a wide range of edentulous, but the financial effort that patients have to make is more dentures, skeletal partial consistent than in the case of a partial acrylic dentures. In this study, we will try to present some dentures essential aspects in the technology of creating flexible partial dentures.

\section{INTRODUCTION}

Elastic or flexible dentures are a modern alternative to classic dentures made of acrylic resins and they are a solution for patients who want to enjoy the benefits of a denture for a long time.

Thus, the material from which these dentures are made is an elastic, thin, resistant and biocompatible with the tissues of the oral cavity. The base of this denture is pink and promotes successful integration into the oral cavity.(1-3)

\section{GENERAL DATA}

There are several types of flexible dentures, depending on the number and distribution of the remaining teeth on the dental arches or depending on their total absence and are named after the materials from which they are made of: Biodentaplast, TCS, Polyon etc.(1,2,3) Among the advantages of flexible dentures that the production companies bring into question, the following must be mentioned:(1,2,3)

$\checkmark \quad$ Does not retain plaque and tartar.

$\checkmark \quad$ Does not affect the support teeth.

$\checkmark \quad$ They are biocompatible and the material does not contain toxic residues.

$\checkmark \quad$ They are durable over time.

$\checkmark$ It has a low stretch on the palate, the taste and pronunciation are not affected, due to the shape and flexibility of the denture.

$\checkmark \quad$ They are very stable, offer great comfort, do not cause injury, allow a fairly effective chewing of food.

$\checkmark \quad$ It offers a superior aesthetic etc.

In general, the dental team (dentist, dental technician) avoids approaching a treatment plan that includes these flexible dentures and especially recommends acrylic and / or skeletal partial denture, usually due to either convenience, either the absolute refusal to inform or to invest in a different technology.
Specifically, the purpose of this study is to familiarize the medical dental team (dentist, dental technician) with the manufacture process of such prosthetic restorations.

Next, we will briefly present the technological workflow of making flexible dentures, both clinical and technical stages:(1,2,3)

Clinical examination of the patient.

Preliminary impression.

Pouring the preliminary model.

Making custom trays.

Functional impression.

Pouring the master cast.

Making wax occlusion rims.

Recording intermaxillary relationships.

Mounting the master casts in the simulator (occluder, articulator).

Duplication of the master cast.

Wax-up Biodentaplast type framework.

Flasking the model.

Obtaining the pattern

Resin injection.

Deflasking.

Processing the Biodentaplast type resin framework.

Making the wax setup of partial denture.

Wax try-in.

Flasking the model with a silicone index.

Packing the acrylate.

Acrylate polymerization.

Deflasking, processing and polishing the partial denture

Deliver the partial denture to patient.

\section{CLINICAL EXAMPLE}

Next, we will exemplify how to obtain a flexible partial denture through a clinical case, focusing mainly on

${ }^{2}$ Corresponding author: Camelia Ionescu, Str. Plevnei, Nr. 19 Sector 1, Bucureşti, România, E-mail: mburlibasa@gmail.com, Phone: +40723 472632 Article received on 22.11.2020 and accepted for publication on 02.03.2021 


\section{CLINICAL ASPECTS}

laboratory steps.

A male patient named Y.S. aged 46 years, presented in the dental office following the loss of masticatory units in the lateral area, masticatory efficiency decreased significantly. To fix this problem, the dentist in collaboration with the patient and the dental technician, decided as a treatment plan to make two Biodentaplast type flexible dentures.

In a first stage, preliminary impressions were made, and preliminary casts were poured. On the preliminary casts two individual impression trays were made. With the help of the individual impression trays (figures no. 1-3), the maxillary and mandibular functional impressions were taken with silicone materials, in which functional casts were poured. On the functional casts, the occlusion rims were made, necessary to record maxillomandibular relationship. The functional casts were then mounted in a simulator in centric relation, with the help of the intermaxillary relationship recorded in the dental office with occlusion rims (figures no. 4, 5).

Figure no. 1. Preliminary impressions taken in stock trays with alginate

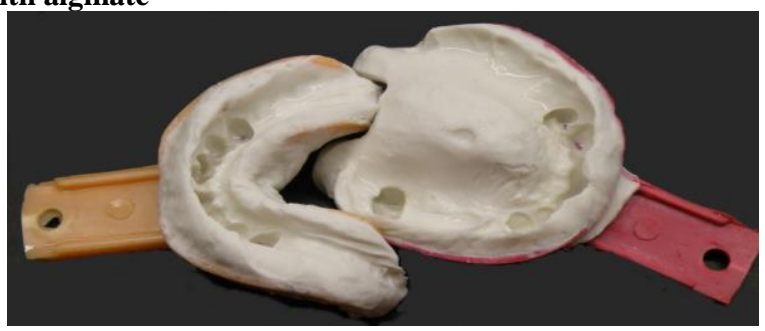

Figure no. 2 a, b. The two preliminary casts, maxillary and mandibular, made of class III plaster, with the limits of the custom trays drawn on them

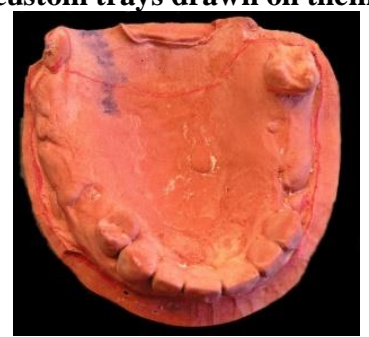

a

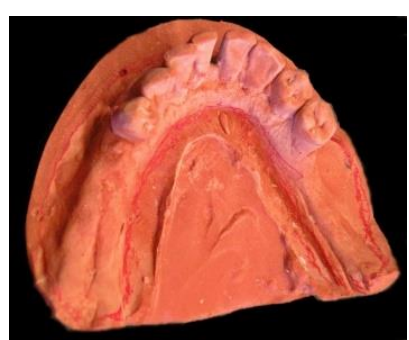

b
Figure no. 3. a, b. Custom trays made of light-curing resin plates.

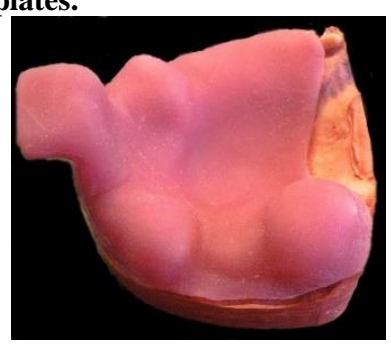

$\mathbf{a}$

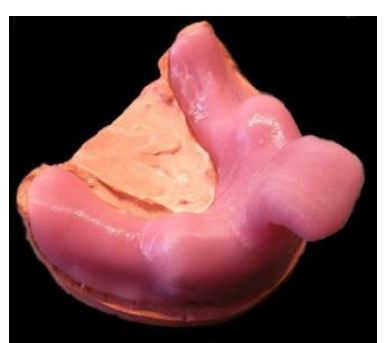

b
Figure no. 4. The master casts mounted in centric relation with occlusion rims

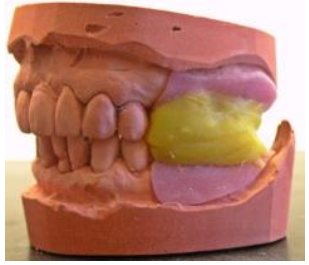

Figure no. 5. Functional casts mounted in occluder

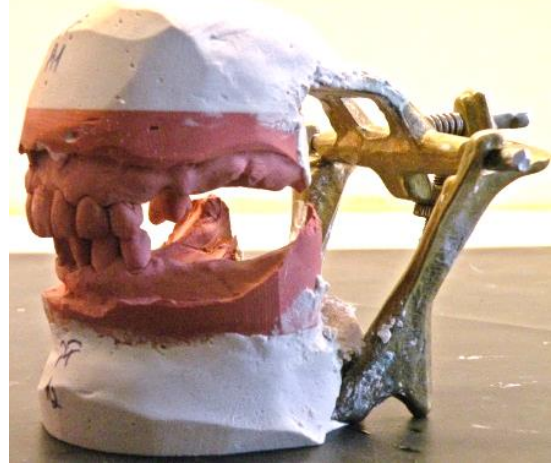

The master casts were duplicated and, on the obtained casts the wax framework of the two flexible dentures were made. The cast were packed in special flasks, specific to elastic resin injection system. The injection of the elastic resin was followed by the deflasking and processing trimming of the denture.

The frameworks obtained were adapted to the master casts (figure no. 6) and then the wax setup of the dentures was made. Subsequently, wax dentures were flasked and the wax was removed. In the pattern obtained the acrylic resin was introduced. After polymerization of the acrylic resin, the final product was deflasked, trimmed and polished. The clasps were made of the same flexible material, from which the base of the prosthesis was made.

This was followed by try-in of the dentures in the oral cavity (figure no. 7-9).

Figure no. 6 a, b. Framework of flexible dentures, mandibular (a) and maxillary (b)

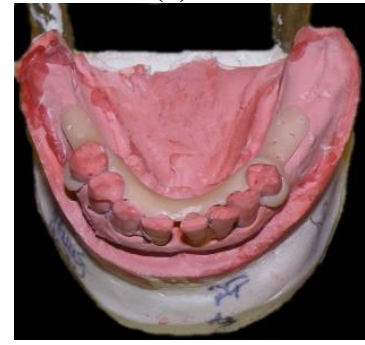

a

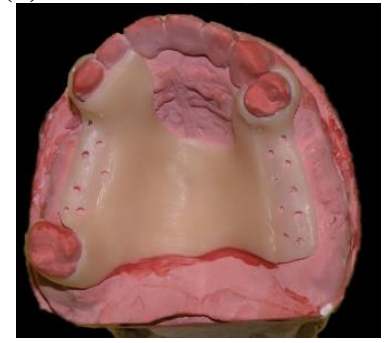

b
Figure no. 7 a, b. Flexible dentures mandibular (a) and maxillary (b) after defalsking

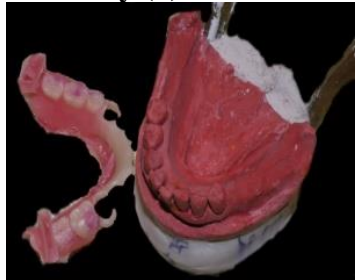

a

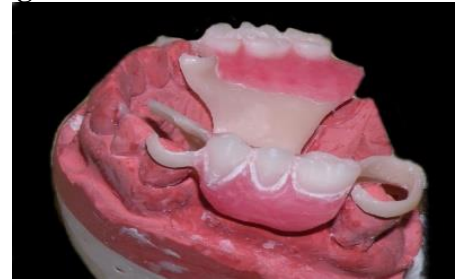

b
Figure no. 8. Mandibular(a) and maxillary(b) flexible dentures after processing

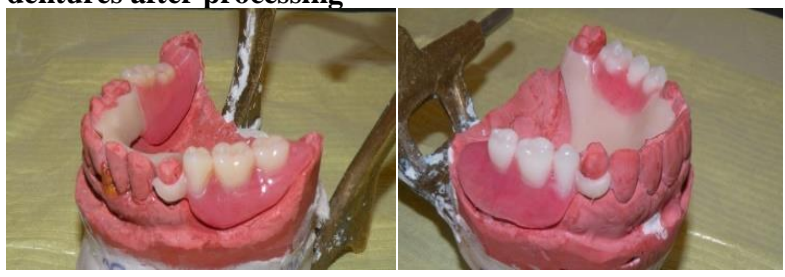

a

AMT, vol. 26, no. 1, 2021, p. 68 


\section{CLINICAL ASPECTS}

Figure no. 9. The flexible dentures in occlusion on master casts

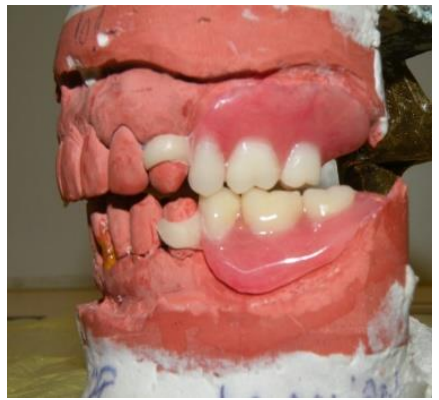

Flexible dentures can be a viable alternative, especially for replacing partial acrylic dentures. Unfortunately, the technology of making such dentures involves some additional financial efforts from the technical department, the dental laboratory, efforts that consist in the purchase of equipment, materials and instruments necessary for the manufacture of such prosthetic restorations. But, all these investments from the dental laboratory will definitely pay off over time, due to higher costs, compared to classic acrylic partial dentures.

Other disadvantages of flexible dentures, apart from the high price, can be systematized as follows:

- They need a rigorous hygiene.

- They can stain over time (especially for smokers and people who drink coffee regularly).(4-6,13)

\section{DISCUSSIONS}

Polyzois in a study conducted in 2015 , showed that, although flexible dentures are prosthetic works that are not learned during faculty, the interest of doctors and technicians in their realization is growing. Long-term success is based on investing in oneself by taking specialized courses in the field, but also in the materials and equipment needed to make flexible partial dentures.(7)

Singh 2013, following a rigorous analysis, concluded that the success of a treatment in which a flexible partial denture is used is based on establishing a correct diagnosis accompanied by establishing a rigorous treatment plan followed strictly.(8)

In an attempt to evaluate how flexible dentures, influence the oral health related to quality of life (OHRQoL) compared to acrylic dentures, Akinyamoju in 2019 found an improvement in OHRQoL for patients wearing flexible partial dentures, which may change future therapeutic behaviour for such patients.(9)

In 2011, Singh conducted an assessment of the satisfaction of using flexible dentures compared to conventional rigid acrylates in a group of 18 patients, with clear results in favour of flexible dentures.(10-12)

\section{CONCLUSIONS}

Flexible partial denture is a widespread prosthetic work, as it can restore any form of partial edentulous spaces.

From a topographical point of view, it was discovered that there are approximately 60,000 clinical possible combinations of teeth and edentulous spaces, these being most often restored with flexible dentures, due to their flexibility and elasticity.

Flexible partial denture is a prosthetic work made of an elastic material that does not contain monomer and is obtained through an injection process and has the ability to restore aesthetically, morphologically and functionally the dental arches.

This type of prosthetic restorations, with clasps made of the same material from which the base of the denture is made offers patients more comfort and a substantial aesthetic compared to the partial acrylic denture.

contributions.

Acknowledgement:

In this article, all the authors have equal

\section{REFERENCES}

1. dentalexcellence. Proteze elastice. [Online] [Cited: 1123 , 2020.] https://www.dentalexcellence.ro/proteze-elasticealternativa-avantajoasa/

2. dentfix. Proteze dentare elastice. [Online] [Cited: 1123 , 2020.] http://www.dentfix.ro/2013/12/protezele-dentareelastice/.

3. Negrescu EC, Malița M. Particularități de realizare a protezelor flexibile de tip Biodentaplast. În: Tendinte moderne în științele biomedicale, Vol. IX, p. 251-297, coordonatori: Malița MA, Dina MN, Ionescu C, David M, Burlibașa M. Editura Matrix Rom, Bucuresti; 2020.

4. Yunus N, Rashid AA, Azmi LL, Abu Hassan MI. Some Flexural Properties of a Nylon Denture Base Polymer. J Oral Rehabil. 2005;32:65-71.

5. Dhiman RK Col, Roy Chowdhury SK. Midline Fracture in Single Complete Acrylic vs Flexible Dentures. MJAFI. 2009;65:141-5.

6. Anusavice KJ. 10th ed. Philadelphia: WB Saunders; 1996. Phillips' Science Of Dental Materials; 1996; p. 238.

7. Polyzois G, Lagouvardos P, Kranjcic J, Vojvodic D. Flexible Removable Partial Denture Prosthesis: A Survey of Dentists' Attitudes and Knowledge in Greece and Croatia. Acta Stomatol Croat. 2015;49(4):316-324. doi:10.15644/asc49/4/7.

8. Singh K, Aeran H, Kumar N, Gupta N. Flexible thermoplastic denture base materials for aesthetical removable partial denture framework. J Clin Diagn Res. 2013;7(10):2372-2373. doi:10.7860/JCDR/2013/5020.3527.

9. Akinyamoju CA, Dosumu OO, Taiwo JO, Ogunrinde TJ, Akinyamoju AO. Oral health-related quality of life: acrylic versus flexible partial dentures. Ghana Med J. 2019;53(2):163-169. doi:10.4314/gmj.v53i2.12.

10. Singh JP, Dhiman RK, Bedi RP, Girish SH. Flexible denture base material: A viable alternative to conventional acrylic denture base material. Contemp Clin Dent. 2011;2(4):313-317. doi:10.4103/0976-237X.91795

11. Mocuța D, Popovici IA, Cristache G, Sfeatcu R, Bodnar T. Impact of the living conditions on population health. Metalurgia International. 2009;14:17-19.

12. Burlibasa L, Chifiriuc MC, Lungu MV, Lungulescu EM, Mitrea S, Sbarcea G, Popa M, Marutescu L, Constantin N, Bleotu C, Hermenean A. Sythesis, physico-chemical characterization, antimicrobial activity and toxicological featurs of $\mathrm{Ag}-\mathrm{ZnO}$ nanoparticles, Arabian Journal of Chemistry. 2020;13(1):4180-4197.

13. Burlibașa M, Cernușcă-Mițariu M, Cernuşcă-Mițariu S, Mițariu M, Malița M. Theoretical and practical aspects related to biomaterials decontamination in dental medicine (with reference to dental prosthetics). Metalurgia International. 2013;(XVIII):4:261-267. 